\title{
Unveiling the concept of transparency: its limits, varieties and the creation of a typology
}

KARINA FURTADO RODRIGUES ${ }^{1}$

${ }^{1}$ Escola de Comando e Estado-Maior do Exército (ECEME) / Programa de Pós-Graduação em CiênCias Militares, RIo de JaneIRo - RJ, BRAZIL

\begin{abstract}
This article aims to unveil the concept of transparency considering its limits, varieties and forms of identification. The premise is that secrecy is vital in the execution of some public policies, which brings different parameters to the analysis of transparency in these contexts if compared with policies that do not need secrecy. The purpose of this article is to fill a gap in the national and international literature, which disregards the different levels of access to information of public organizations citizens can have. Therefore, through the application of Goertz (2006a) model of concept formation on Michener and Bersch's (2013) concept of transparency, and also considering the transparency varieties and directions mentioned by Hood and Heald (2006), the study proposes a typology with four non-mutually exclusive subtypes of transparency in organizations: the fuller transparency, the nominal transparency, the conditional transparency and the transparency in the allocation and management of sensitive information. The typology reveals a myriad of different layers of access to information and analysis that enable more precise transparency evaluations of public institutions. Finally, the definitions and the analytical possibilities of each of the subtypes are discussed.
\end{abstract}

Keywords: Transparency. Conceptualization. Adjectivizing. Access to information. State secrecy.

\section{Desvelando o conceito de transparência: seus limites, suas variedades e a criação de uma tipologia}

\section{Resumo}

Este artigo se propõe a desvelar o conceito de transparência levando em conta seus limites, suas variedades e suas formas de identificação. Parte-se da premissa de que o sigilo é vital na realização de algumas políticas públicas, o que faz com que a análise de transparência nesses contextos tenha parâmetros distintos de políticas que não necessitam de sigilo. Almeja-se preencher uma lacuna na literatura, que desconsidera os diferentes níveis de acesso à informação pelos cidadãos existentes nas organizaçães públicas. Por meio da aplicação do método de construção conceitual de Goertz (2006a) ao conceito de transparência de Michener e Bersch (2013), também considerando as variedades e os tipos de transparência abordados por Hood e Heald (2006), propõe-se uma tipologia que conta com quatro subtipos de transparência nas organizações: a (1) transparência plena; a (2) transparência nominal; a (3) transparência condicionada; e a (4) transparência na atribuição e gestão de informações sigilosas. A tipologia revela uma gama de diferentes níveis e formas de transparência nas organizações, não mutuamente excludentes e capazes de aferir com maior precisão a real transparência das instituições. Por fim, discutem-se as definições e as possibilidades analíticas de cada um dos subtipos.

Palavras-chave: Transparência. Conceitualização. Adjetivação. Acesso à informação. Segredos de Estado.

\section{Desvelando el concepto de transparencia: sus límites, sus variedades y la creación de una tipología}

\section{Resumen}

Este artículo se propone desvelar el concepto de transparencia teniendo en cuenta sus límites, variedades y formas de identificación. Se parte de la premisa de que el secreto es vital en la conducción de algunas políticas públicas, lo que hace que el análisis de transparencia en estos contextos tenga parámetros distintos de las políticas que no necesitan sigilo. Se pretende colmar un vacío en la literatura, que desconsidera los diferentes niveles de acceso a la información existentes en las organizaciones públicas por parte de los ciudadanos. Al aplicar la literatura de formación conceptual de Goerz al concepto de transparencia de Michener y Bersch, también teniendo en cuenta las variedades y direcciones de transparencia trabajadas por Hood y Heald, se propone una tipología que cuenta con cuatro subtipos de transparencia no mutuamente excluyentes en las organizaciones: 1) la transparencia plena, 2) la transparencia nominal, 3) la transparencia condicionada; y 4) la transparencia en la asignación y gestión de información confidencial. La tipología revela diferentes niveles y maneras de transparencia en las organizaciones, no mutuamente excluyentes y capaces de evaluar con mayor precisión la verdadera transparencia de las instituciones. Por último, se discuten las definiciones y las posibilidades analíticas de cada uno de los subtipos.

Palabras-clave: Transparencia. Conceptualización. Adjetivación. Acceso a la información. Secretos de Estado.

Article submitted on December 09, 2017 and accepted for publication on September 18, 2018.

[Translated version] Note: All quotes in English translated by this article's translator.

This article portrays a study conducted as part of my PhD dissertation. I am grateful for the PhD scholarship granted by the Pró-Estratégia/CAPES program, and for the opportunity of a doctoral stay abroad provided by the PDSE/CAPES program. I would like to thank the scholars who contributed to this work by reading the previous versions of this article and offering helpful inputs: Octavio Amorim Neto (FGV EBAPE), Professor Gregory Michener (FGV EBAPE), Professor David Mares (CILAS/UCSD), and Professor Angelo Brigato Ésther (FACC/UFJF).

DOI: http://dx.doi.org/10.1590/1679-395173192x 


\section{INTRODUCTION}

Transparency is a worldwide issue discussed both at the global level through initiatives such as the Open Government Partnership and at the local level through national and even municipal freedom of information laws. Since the middle of the twentieth-century, informational asymmetries have gained the attention of economists concerned about market stability (FORSSBECK and OXELHEIM, 2014; MICHENER and BERSCH, 2013). Recently, the debates on governance and efficiency in the public sector have fueled the discussions on transparency as they consider actors external to the government both as operators and evaluators of public policies (BEVIR, 2010; DONAHUE, 2004; PETERS and PIERRE, 1998; SHAH, 2006). Finally, the development of information technology and the increasing discussion around open data - which produces a multitude of information and possibilities for data crossing - also contributed to bringing attention to the theme of transparency (IGLESIAS, 2017; JANSSEN, CHARALABIDIS and ZUIDERWIJK, 2012; MOLLOY, 2011).

However, the term transparency may be the subject of many interpretations. One could wonder if transparency is something real, feasible, or an allegory (or all three at the same time). This article assumes that the concept of transparency has not been adequately defined in the literature on public policy evaluation (ABDALA and TORRES, 2016; BAIRRAL, COUTINHO and ALVES, 2015; CRUZ, FERREIRA, SILVA et al., 2012; GRUMAN, 2012; MONTEIRO, 2014; PRADO, 2006). This tends to reduce the meaning of transparency as the maximum disclosure of government information (ARTICLE 19, 1999). However, no public organization or the state can be completely transparent since many public processes and policies are subject to secrecy based on the nature of the action.

Therefore, the issue of limits, variety, directions, and identification of transparency gain special importance in the task of rethinking the structures of control in force in public administration, considering the perspective of a viable transparency and respecting the nature of each type of information. This study uses the literature on conceptualization as a method to propose four subtypes of transparency that can coexist in public organizations: (1) full transparency; (2) nominal transparency; (3) conditional transparency; and (4) transparency in the allocation and management of sensitive information.

This article is divided into four parts, in addition to this introduction. The second part explores the literature on transparency and its conceptualization, considering its constitutive elements, dimension, varieties, and the concepts most often misused as transparency. The third section presents how social science conceptualizes transparency and how it is used as a method of analysis. These issues are supported by the works by Sartori (1970), Goertz (2006a), and Collier, Hidalgo and Maciuceanu (2006). The fourth part of the article discusses the four subtypes of transparency, ranging from maximum to minimum restriction to access. Finally, the last part presents considerations about the field of study, its limitations, and the possible applications of the conceptual typology presented.

\section{ORIGINS OF THE TERM AND EXISTENT CONCEPTS}

The term "transparency" was only used in a political-economic sense in 1987 (MICHENER and BERSCH, 2013, p. 235). However, the concept is older than the use of the term. Since the nineteenth-century, the publicity of the state's acts was already a prominent theme, as observed in the works of Jean-Jacques Rousseau and Jeremy Bentham, and the debates about the benefits of the "marketplace of ideas" in the efficiency of political decisions (BENTHAM, 1843; COLARESI, 2014; HOOD and HEALD, 2006; INGBER, 1984; MICHENER and BERSCH, 2013).

At the end of the nineteenth-century, Bentham studied in depth the publicity for the acts of state agents, considering it as the cure to the temptation to abuse power. For the author, any governmental position should imply costs for any type of abuse, which would be judged by the public. In addition, the existence of small groups of people in assemblies would not be sufficient to monitor those in such positions. Optimistically, the author predicted that, with complete transparency, the exchanges of ideas that took place within a small assembly could occur on a national scale, increasingly restricting illegal acts by people in public positions (BENTHAM, 1843; GAONKAR and MCCARTHY, 1994).

The modern concept of the "marketplace of ideas" corroborates Bentham's thoughts. The notion of "marketplace of ideas" appears for the first time in the debates on the first constitutional amendment of the United States of America (USA), which established the right of free speech. The concept assumes that, in a society where every citizen has free access to information, 
there could be a real competition of ideas, as in the economic markets, where only the best initiatives would last. Both Bentham's idea of publicity and the concept of the market of ideas neglect several aspects and difficulties of exchanging information and forming public opinion. They wrongly assume that everyone has the same capacity to understand all kinds of information and fail to acknowledge the existence of restricted ideological groups that do not access information that does not corroborate their point of view (BLOCHER, 2008; INGBER, 1984).

Informational asymmetry appears strongly in the studies of several economists in the second half of the twentieth century to account for the imperfections of the dissemination of information. This occurs in the same frenzy as the waves of transition and consolidation of democracy around the world, which brought into question the political opening and the construction of new institutional mechanisms to tackle financial fraud, both from states and actors in the financial market (FORSSBECK and OXELHEIM, 2014; MICHENER and BERSCH, 2013).

In this context, transparency has become not only a tool for fighting corruption but something rhetorically moral. It is assumed that "the greater the involvement of society in acts of public governance, the more management is expected to focus on efficiency, efficacy, and effectiveness in the use of public resources. Furthermore, only after having this information, will citizens be able to choose their representatives better" (BAIRRAL, COUTINHO and ALVES, 2015, p. 646, our translation).

In the 1990s, governance literature helped to increase the use of the term transparency. The studies on governance at that time changed the view of how the state should act. If in the past the state should only use its own resources, in the perspective of governance the state becomes a coordinator of solutions, able to use different actors and resources to offer solutions in public policies, as well as make collective decisions, including with the private sector and civil society (BEVIR, 2010; DONAHUE, 2004; PETERS and PIERRE, 1998). Collective decisions, in this case, also means outsourcing to society part of the costs related to control activities, which can only be done by adopting transparency mechanisms (SHAH, 2006).

The dissemination of the subject facilitated the emergence of all kinds of misuse and conceptual stretching regarding the necessary adoption of transparency in governments (MICHENER and BERSCH, 2013; ZUCCOLOTTO, TEIXEIRA and RICCIO, 2015). Many scholars have neglected the possible side effects of transparency in public policies, especially in areas operating with sensitive information. Some studies, however, are weighing this issue when exploring topics such as national defense (POZEN, 2014; THOMPSON, 1999), international relations (LORD, 2006), and studies regarding central banks (MOORE, 2011). According to Lord (2006), greater transparency does not necessarily lead to the strengthening of democracy in an international environment: while helping well-intentioned non-governmental organizations, releasing sensitive information may unintendedly serve para-state or fundamentalist armed groups.

Pozen (2014) addresses this debate through the repeated justification of the US government in denying information based on the "mosaic theory." According to this theory, potential enemies could gather small pieces of information and complete a data mosaic that would hinder the development of security or defense policies. The justification is relevant, but it can lead to a state of secrecy that may violate democratic principles of transparency. Therefore, the limits of such theory are not yet clear.

Therefore, it is worth considering how to conceptualize transparency while considering its daily operation and practical issues, as well as the limits of its benefits and the different nature of the information. The next subsections explore the current situation of the studies on transparency. The studies mentioned below discuss how to identify transparency in organizations; the variations in transparency regarding the timing of disclosure, how disclosure is targeted, and the contexts that facilitate or hinder access; and, finally, the differences between transparency and related concepts such as accountability and democracy.

\section{Defining transparency through its constitutive elements}

Michener and Bersch (2013) offer a concept of transparency based on elements that identify it, i.e., based on what constitutes transparency. The authors found inspiration in the work "Conceptualizing accountability" by Schedler (1999) and build a concept that allows "identifying" transparency. For Michener and Bersch (2013), transparency can be recognized based on two elements, both necessary and sufficient when together ${ }^{1}$ - visibility and inferability.

\footnotetext{
${ }^{1}$ Translator's note. In the Portuguese version of this article, the author explains the challenge of translating the terms proposed by Michener and Bersch (2013) into Portuguese, considering that many of these terms were coined by the scholars, i.e., they are new words in English. The author clarify that this matter is not discussed in this article. She recognizes the need for a debate on a better form to express these concepts in Portuguese, welcoming any efforts in this direction.
} 
Visibility is formed by the indicators (1) completeness and (2) findability, i.e., how easy it would be to find the data. If data is not complete, it is impossible to create the complete panorama of a subject. As for findability, the ease if discovering information is influenced either through active transparency (available and published on the internet and other means) or passive transparency (when an agency responds to a request for information).

The visibility of information has been on the agenda of most pro-transparency movements so far (ABDALA and TORRES, 2016; BAIRRAL, COUTINHO and ALVES, 2015; CRUZ, FERREIRA, SILVA et al., 2012; MONTEIRO, 2014; PRADO, 2006). However, Michener and Bersch (2013) pointed out a new wave of studies advocating the centrality of the quality of information, since it is not rare for the disclosed information to lack intelligibility, be difficult to visualize, or furnished in formats that are hard to work with (BARROS and RODRIGUES, 2017; MONCAU, MICHENER, BARROS et al., 2015).

Consequently, the ability to infer conclusions from data (inferability) has become as important as visibility for transparency (MICHENER and BERSCH, 2013). Inferability can encompass numerous elements since the ability to infer something from information depends on the subject that requested the data - if they are a citizen who is not familiar with the topic, aggregated data may be sufficient. On the other hand, if they are a researcher seeking a complete database to perform statistical tests, the information has to be more complex. In the original concept by Michener and Bersch (2013), the authors cite three possible conceptual levels: (1) disaggregation, (2) verifiability, and (3) simplification.

A disaggregated data is highly detailed information that satisfies the demands of researchers, academia, and journalists looking for a thorough analysis of government actions. Verifiability concerns the existence of a third actor or institution that audits the accuracy of the data. Finally, simplification is about the ease of visualization and understanding by a broader audience.

Several aspects of transparency, however, were not covered by the concept put forward by Michener and Bersch (2013). Hood and Heald (2006) explored different dimensions and varieties of transparency in their book "Transparency: the key to better governance?" The authors' contribution to advance the concept of transparency is discussed in the next subsection of this article.

\section{Dimensions and types of transparency}

Hood and Heald (2006) state that many concepts of transparency become ambiguous because they do not consider (1) the directions and (2) the varieties of transparency. Regarding directions, the authors suggest transparency may be vertical and horizontal, internal and external. Thus, there are four directions resulting from the possible combinations:

1. Transparency upwards: is hierarchical and the principal monitors the agent.

2. Transparency downwards: the agent accesses information and monitors the principal.

3. Transparency outwards: the agent observes the outside of the organization.

4. Transparency inwards: observers from outside can visualize what happens inside the organization.

Most research on transparency focuses on upwards and outwards transparency, in which the citizen is the principal, and the government is the agent (BIRKINSHAW, 2010; GRIMMELIKHUIJSEN and MEIJER, 2012). However, limiting the analysis only to this direction means to overlook, for example, the active role of governments in monitoring citizens, whether through tax systems or through mass espionage - which are clear examples of transparency downwards. Directions can have effects on the elements of visibility and inferability studied by Michener and Bersch (2013). Using the previous example of espionage, it is unlikely that citizens will know for sure whether they are being spied on and to what extent. This type of information is only available when there are information leaks, and, in Brazil, there is no specific legislation to protect whistleblowers.

In addition to the directions, Hood and Heald (2006) identify several varieties of transparency, which add some type of status to the information disclosed. The varieties are (1) event versus process transparency, (2) transparency in retrospect versus transparency in real-time, and (3) nominal versus effective transparency. 
Event versus process transparency accounts for the fact that having transparency in events is simpler than having transparency in processes. According to the authors, events are easily measurable "points" or "states" of public policy. The processes, on the other hand, are related to the various measures taken to implement a policy, throughout its development. It may also be related to social and economic change in the long term, which are the most difficult to measure (HOOD and HEALD, 2006).

Based on the systems theory, the authors consider process as (1) the event of defining inputs, which are directly measurable through elements such as budgets and purchases; (2) the transformation processes, which are the execution of the tasks that will transform inputs into outputs, reasonably measurable; (3) the event of the outputs, measurable through proxies ${ }^{2}$ linked to the actions taken; (4) the processes of connection, which are little known, and show the connections between the action and the public policy's result; and, finally, (5) the result, which is difficult to measure and its understanding depends on a long-term analysis of the public policies outcomes.

In this context, events are easier to access in terms of transparency because they are more easily measurable. When seeking transparency of processes, in turn, one enters the black box of the organizations' operation. Institutions may even be transparent about the rules regarding their internal policy enforcement processes. However, there is a high level of discretion among agents, which is rarely revealed to observers outside the organization. In such cases, it is feasible to think of institutional arrangements that deal with discretion and the generation of transparency inwards (monitoring institutions), as addressed by literature on street-level bureaucracy (LIPSKY, 2010; THOMPSON, 1983) ${ }^{3}$.

The idea of transparency in retrospect versus transparency in real-time adds the temporal aspect of information to the concept of transparency (CLEARY and MCCONVILLE, 2006; HOOD and HEALD, 2006). When transparency is in retrospect, the organization is allowed to release information within a certain period, both for the systematization of information and for the protection of the public policy implementation. Transparency in retrospect, is a key element in dealing with personal information that requires confidentiality. It is this notion that supports the rules to restrict access to a document, establishing the limit of confidentiality when related risks decrease. This variety of transparency affects both the visibility and the inferability of the information, and it will be considered in the construction of a new conceptual model in the third part of this article.

Transparency in real-time is the constant monitoring of an action, which can occur in isolated points, as well as in actions that are traditionally confidential. This was the case with the entry of the Military Police of the State of Rio de Janeiro into the 'Maré' complex of favelas. The operation was announced days before in all media, a procedure intended to avoid bloodshed $(G 1,2014)$. Other examples of transparency in real-time are live broadcasts of assemblies and polls and the use of open data in real-time.

Finally, nominal versus effective transparency shows the difference between the simple disclosure of data and actually processed, treated, and useful transparency. Sometimes a large amount of data is available, but the information is useless for public scrutiny and analysis, or too complex to understand (HOOD and HEALD, 2006). Comparing these varieties with the concept of transparency based on visibility and inferability, it is possible to establish a relationship between nominal transparency and visibility, and effective transparency and inferability, considering them as synonyms.

\section{Differences between transparency, accountability, and democracy}

The effort to properly define a concept entails the need to establish what the definition will not encompass. Therefore, this section explores two misunderstandings in the literature, the confusion between transparency and accountability and between transparency and democracy. With regard to conceptual overlap with accountability, the differences between the two concepts are subtle, and often achieving one depends on achieving the other. According to Hood (2010, p. 989):

\footnotetext{
${ }^{2}$ For those unfamiliar with the jargon of quantitative methodology, proxy is a variable not directly relevant to the analysis, but that substitutes one that is important but considered as immeasurable. A common example is the measurement of quality of life. As it is not possible to measure quality of life objectively, studies use proxies such as gross domestic product (GDP) to assess the variable.

${ }^{3}$ Literature on street-level bureaucracy seeks to find institutional formats that reduce the discretion of bureaucrats working directly in contact with citizens or the private sphere. Such bureaucrats have a decision-making power impossible to be constantly monitored by superiors, therefore, the format of the institution may reduce monitoring costs in the principal-agent relationship (LIPSKY, 2010). A classic example of street-level bureaucracy is the police. Institutional control includes work in pairs and the rotation of work partners.
} 
Accountability broadly denotes the duty of an individual or organisation to answer in some way about how they have conducted their affairs. Transparency broadly means the conduct of business in a fashion that makes decisions, rules and other information visible from outside.

The view of transparency and accountability as intrinsically inseparable is quite common in the literature and assumes that one concept could not exist without the other. However, when defining transparency as making information available to citizens, this perspective ignores that the direction of accountability may not turn to the public, but to control bodies such as courts of accounts, prosecutors, or internal affairs. This means that the public, in general, may not know the details of the agents' actions, even though the agents are accountable in the eyes of controllers (HOOD, 2010). According to the institutionalist view of checks and balances, accountability must entail transparency in some direction (not necessarily in all directions).

The two concepts can also be seen as dissociable and mutually reinforcing, generating good governance. However, this may not always be a good combination. Hood (2010) stresses that excessive transparency can create defensive and automatic responses from agents, leading to an illusion of inclusion that is nothing more than one-way communication. In addition, when there is a high level of determination for transparency, politicians and bureaucrats may, for example, unnecessarily attribute a higher level of secrecy to information.

Schedler (1999) identifies answerability and enforcement as elements constituting accountability, contributing to differentiate accountability and transparency. Answerability refers to the notion that the agent is required to inform their actions to another party, even if they are not willing to do so. This task involves not only informing about the actions (i.e., reliable creation and maintenance of the records) but also explaining them to the principal. Enforcement, on the other hand, has to do with applying the rules stipulated through two mechanisms - encouraging good behavior and punishing deviations. According to Schedler (1999), these two mechanisms are necessary and together sufficient to guarantee enforcement.

When observing the concepts of transparency (MICHENER and BERSCH, 2013) and accountability (SCHEDLER, 1999) as explained above, it is possible to consider transparency as part of "answerability," one of the elements of accountability. In the context of state governments, for example, governors must be accountable both to citizens in general and to the state court of accounts (BARROS and RODRIGUES, 2017). According to the agency theory, the government is the agent, and citizens and the court of accounts are the principals. However, complete transparency is more severely required in the case of the courts of account since this principal has a sanctioning power. In this example, citizens are not such a priority as the court of accounts in the institutional hierarchy of the actors. Thus, focusing on the citizen's perspective, it is possible to observe accountability without complete transparency - as long as there is transparency toward the demands of the court of accounts.

When discussing the conceptual overlap between transparency and democracy, the general wonder is whether it is possible to conceive the concept of democracy without transparency. Some authors have considered the two concepts as inseparable (HOLLYER, ROSENDORFF and VREELAND, 2011). The crisis of representative democracy has increasingly strengthened the notion that civil society directly monitoring the government will lead to good governance, which some authors call 'monitory democracy' (KEANE, 2009, 2011; RODRIGUES, 2013).

The advantages of transparency for democracy are widespread. Transparency is helpful in fighting corruption by strengthening accountability and also offers the opportunity for citizens to challenge the government's decisions and procedures. Although transparency has been historically neglected, there is no doubt of its importance. It needs to be built with constant efforts from the government and civil society.

Notwithstanding, the relation between transparency and democracy poses another question to be discussed: is it possible to conceive democracy without opacity? In the article "Democratic secrecy," Thompson (1999) explores several situations when democratic states gave up transparency without necessarily giving up democracy. There are many examples of this "democratic" need for secrecy in the sectors of national defense and public security. These agencies would not be able to conduct their activities without some kind of information retention. Schoenfeld (2010) argues that if accountability - in the sense of taking responsibility - is as important for democracy as transparency, newspapers that disclose secret government strategies should be held responsible for hindering the progress of these policies. 
It is undeniable that certain policies need secrecy and equally undeniable that governments are abusing the right to keep secrets. In the Brazilian case, for example, there was recurring news about hidden, destroyed, or unpublished military and civil intelligence documents (LEALI, 2015; LOPES and KONRAD, 2013; RODRIGUES, 2017). Internationally, the opacity of mass espionage and torture programs in prisons has also been heavily criticized (SAGAR, 2013). The fact is that democracies deal with both transparency and the secrecy of information. The big difference lies in the fact that, in democracies, secrecy must be the result of consensus.

Against this backdrop, the next section presents the literature on conceptualization in the social sciences as a method of analysis and construction of a more comprehensive concept of transparency, considering its constituent elements, dimensions, and varieties.

\section{A CONCEPTUALIZATION METHOD}

Sartori (1970) identified the lack of rigor in the construction of concepts in the social sciences when publishing the article "Concept misinformation in comparative politics." For the author, social sciences are interested in all possibilities brought by the broad access to statistical analysis tools, even though the use of such tools may distance the research from a more critical evaluation of the concepts studied.

The debate that Sartori (1970) started years ago continues nowadays. Important publications in the last two decades brought new energy to these queries, expanding research possibilities, bringing qualitative studies closer to the positivist paradigm, questioning the validity of the exaggerated focus on measurement, and criticizing conceptual stretching - process of removing some elements from a concept, making it possible to compare a larger number of cases. In the author's point of view, this process does not generate better research, but less accurate analysis on a large number of cases (FALLETI and LYNCH, 2009; GOERTZ, 2006a; MAHONEY and VANDERPOEL, 2015; SARTORI, 1970).

For Goertz (2006a), concepts can be considered as structures that receive a meaning with theoretical and empirical assumptions about an object, far beyond a semantic evaluation. Ultimately, "concepts are theories about ontology: they are theories about the fundamental constitutive elements of a phenomenon" (GOERTZ, 2006a, p. 5), in the sense that they define the central characteristics of a phenomenon and its inter-relations. The ontological view of concepts offers a distinction between a concept's symptoms and its constitutive elements. One example is the concept of democracy: free elections are not a symptom of democracy, but the very process that defines it.

An ontology about a concept can, therefore, generate very different conceptions of its constitutive elements and how to measure or classify them. Goertz (2006a) operationalizes the construction of concepts by structuring them in three levels. The first conceptual level is the basic one, which consists of the central concept used in the theoretical propositions. The secondary-level is formed by all the constituent dimensions of the basic-level, which must reflect the ontology chosen by the author. The third level presents the indicators, in which cases are measured or classified. Adcock and Collier (2001) propose that the researcher takes the "opposite path," investigating whether the results of the indicators corroborate the measurement strategy, whether the measurement corroborates the presence and format of the concept's constitutive elements, and finally, whether the constitutive elements remain part of the concept.

The most common way to structure the relationship between elements of a concept is through necessary and sufficient conditions (GOERTZ, 2006a), as well as studied by Wickham-Crowley (1991). An element is necessary when a phenomenon does not occur without it. The element alone, however, cannot cause the phenomenon. An element is sufficient when its presence alone causes the phenomenon (AMORIM NETO and RODRIGUEZ, 2016; MAHONEY, KIMBALL and KOIVU, 2009).

Goertz (2006a) proposes the use of the family resemblance structure when forming concepts. Family resemblance works with the idea that some elements (or group of elements) of a concept are substitutable, i.e., they may not fit into the condition of necessary or sufficient elements to cause a phenomenon. Building a concept using family resemblance means establishing that the presence of "indicator A" or the presence of "indicator B" (indicating with plus sign +) may be necessary or sufficient for a concept's secondary level. 
It is not always possible to find substitutable elements. However, even necessary elements have different degrees of importance in a concept. Therefore, it is possible to infer that each necessary condition has a degree of substitutability. The most substitutable necessary condition approaches triviality, and the least substitutable would approach sufficiency (GOERTZ, 2006a, 2006b). In the case of the concept of transparency by Michener and Bersch (2013), there are substitutable elements only in the secondary-level concept "inferability."

Another tool proposed by Goertz (2006a) is the use of adjectives in forming concepts. Adjectivizing a concept can help understanding specific topics that generalist concepts do not capture. The author states that, in general, adding adjectives to a concept can restrict or increase the number of cases covered by a certain conceptual ontology. Using the concept of democracy as an example, adding "presidential" or "corporatist" to "democracy" reduces the number of countries that can be analyzed. Likewise, a broader concept of democracy would be an electoral regime - which can occur in both democracies and authoritarian environments, depending on where the regime is in the authoritarianism-democracy continuum, different adjectives are added. This relationship can be seen in Figure 1.

Figure 1

\section{Concepts $+/$ - adjectives and the authoritarianism-democracy continuum}

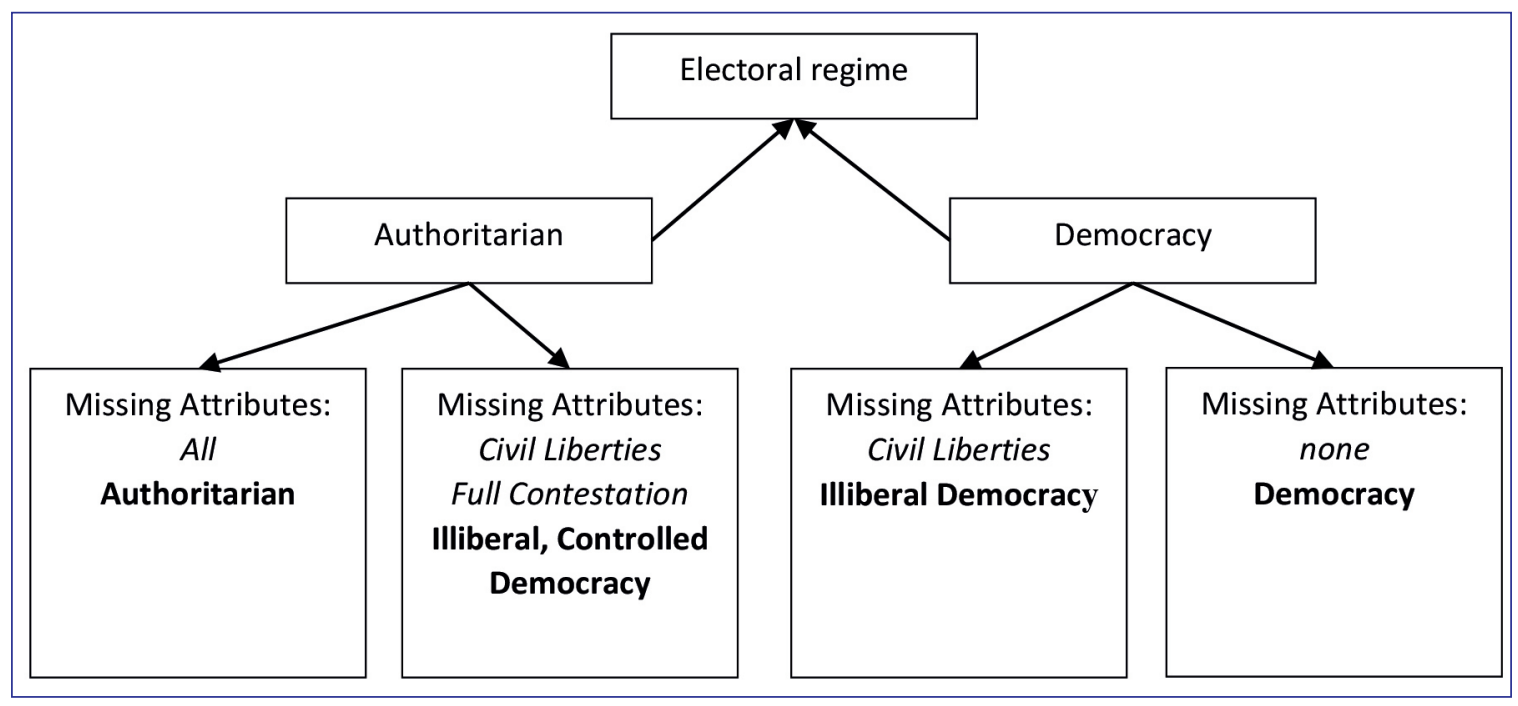

Source: Goertz (2006a, p. 82).

The concept of democracy occurs when all the democratic attributes are present; when civil liberties are suppressed, the concept of Illiberal democracy arises; when civil liberties and contestation are suppressed, "illiberal, controlled democracy" appears; and when all attributes are missing, there is an authoritarian electoral regime. Each of these adjectivized concepts reflects characteristics not captured by the macro concept "electoral regime." A similar process can be applied to the concept of transparency, explored in the following sections. 


\section{APPLYING THE METHOD: FOUR TYPES OF TRANSPARENCY}

This section presents a conceptual model to assess transparency not as an absolute value, but as a possible degree of disclosing information according to the reality of each institution and type of policy. There is a vast literature on transparency, but most authors do not use the debate explored by Goertz (2006a), Sartori (1970), or Adcock and Collier (2001) when structuring the concept, which often leads to conceptual stretching.

The Goertz's (2006a) three-level conceptual building help to visualize the ontology of the research object, not only because of the author's need to justify the choice of the second level elements, but also when requesting clarity in the definition of the relationships between the variables. Michener and Bersch (2013) bring a concept of transparency that is clear and easily applied to concrete cases of public administration. Incorporating Goertz's conceptual discussion (2006a), the authors' concept of transparency can be represented, as shown in Figure 2.

Figure 2

The three-levels concept of transparency

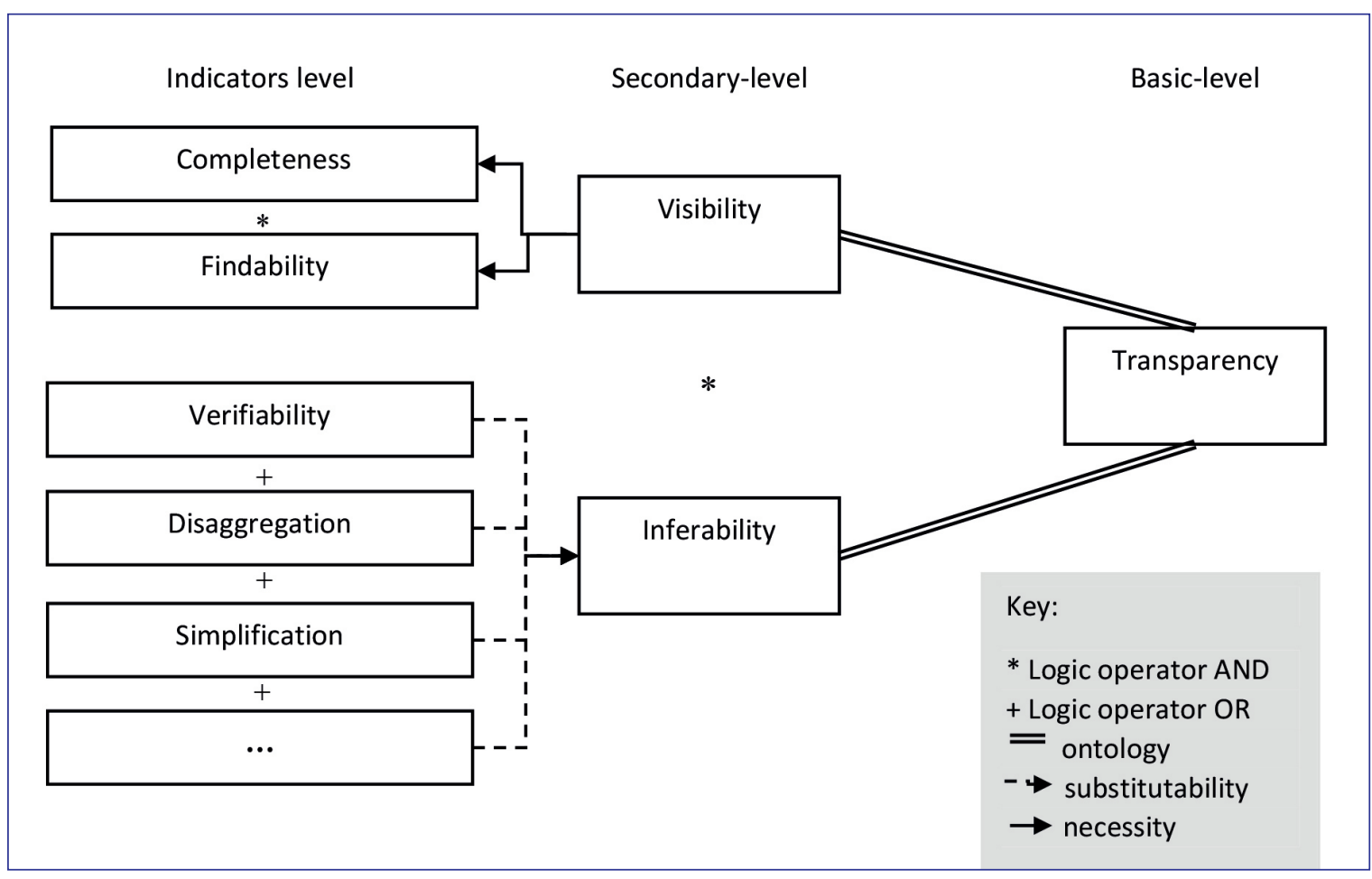

Source: Elaborated by the author based on the concept by Michener and Bersch (2013).

The way transparency is identified in Figure 2 does not yet consider the varieties of transparency and the need for secrecy in some policies. An institution that classifies many documents or deals with personal information (personal data has 100 years of secrecy, according to the current Brazilian legislation - Law 12527/2011), for example, does not fulfill the visibility requirement. This type of information fits what Hood and Heald (2006) define as "transparency in retrospect" since the information only can be disclosed a long time after it was generated. Both content and the reason for the classification of confidential documents are restricted. What is known about a classified document, at least in Brazil (according to Decree No. 7,845 / 2012), is its classification code.

To assess the transparency of institutions that deal with temporarily inaccessible documents, it is necessary to consider the restrictions related to the activity. Therefore, how is it possible to deal with the need for secrecy within the debate around the concept of transparency? Could a classification code be considered sufficient information for the element's visibility or 
inferability? The varieties of transparency proposed in the second part of this article offer some evaluation parameters, such as process transparency and transparency in retrospect, which establish checks and balances regarding the issue of secrecy.

The process of using adjectives to form a concept put forward by Goertz (2006a) was used to build a concept of transparency that considers these institutional aspects. As a result, different configurations (limitations) of the two secondary-level elements of transparency generate different types of transparency. Rather than using adjectives for the presence or absence of attributes (Figure 1), the study adjectivized transparency according to the degree of restriction that the constitutive elements of transparency (visibility and inferability) can assume (Box1) so that the transparency can still be measured.

\section{Box 1}

\section{Restrictions of visibility and inferability}

\begin{tabular}{|c|c|c|c|}
\hline & & \multicolumn{2}{|c|}{ Visibility } \\
\hline & $\begin{array}{c}\text { Restriction of secondary-level } \\
\text { elements }\end{array}$ & More restriction & Less restriction \\
\hline \multirow{2}{*}{ 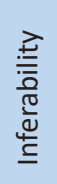 } & More restriction & $\begin{array}{l}\text { (4) Transparency in the allocation } \\
\text { and management of sensitive } \\
\text { information }\end{array}$ & (2) Nominal transparency \\
\hline & More restriction & (3) Conditional transparency & (1) Fuller transparency \\
\hline
\end{tabular}

Source: Elaborated by the author.

In this case, the use of adjectives to form the concept results in four transparency subtypes, in a $2 \times 2$ matrix where (1) fuller transparency has no restrictions on visibility and inferability; (2) nominal transparency has restrictions only on inferability; (3) conditional transparency (transparency upon request) has restrictions only on visibility; and (4) transparency in the allocation and management of sensitive information, presents restrictions in both elements. Using the same presentation as Figure 1 , Figure 3 shows the use of adjectives to form the concept of transparency.

Figure 3

Adjetivizing the concept and the four transparency subtypes

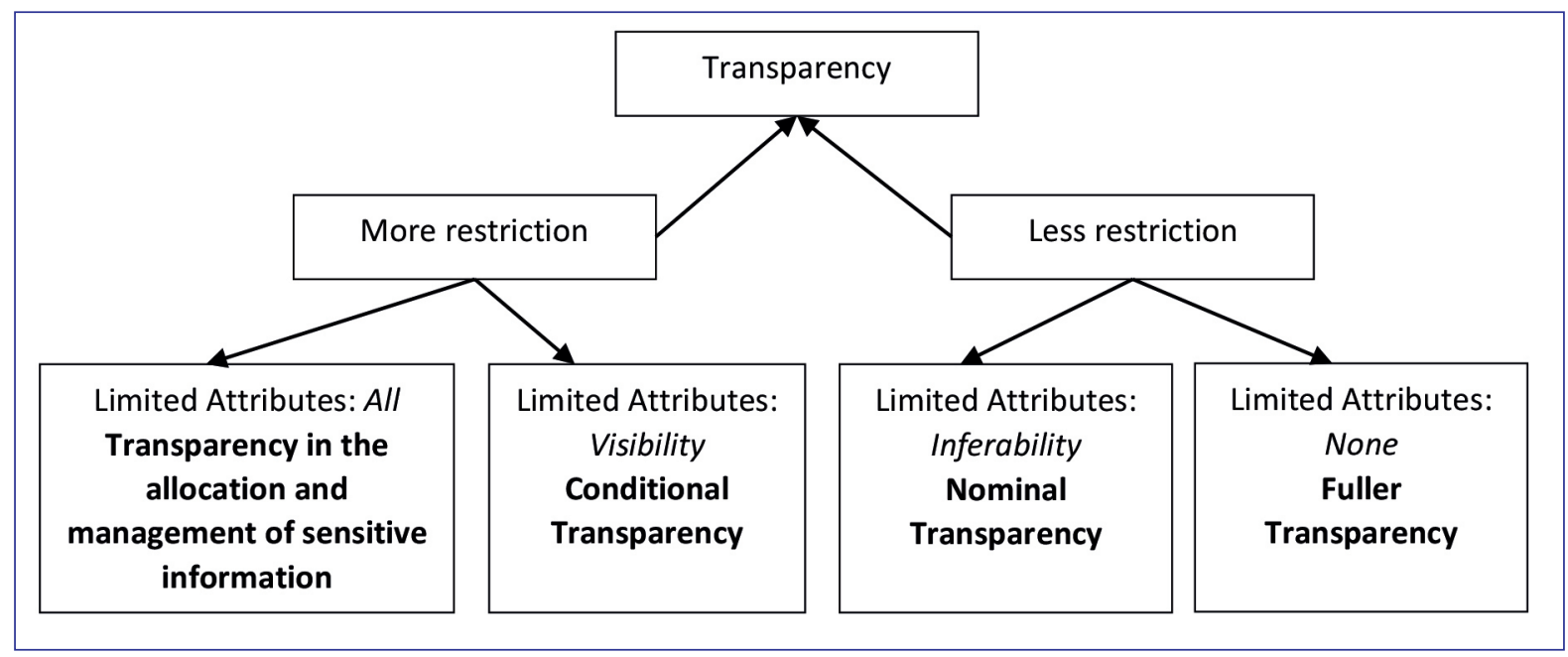

Source: Elaborated by the author. 
When analyzing the four subtypes of possible democratic transparency, visibility and inferability may vary, but they are never extinguished. This is because, even at a very low level, these elements are, ontologically, the definers of the very existence of transparency. Thus, these elements are not substitutable (GOERTZ, 2006a). The next subsections discuss each subtype and how they affect future transparency assessments.

\section{Fuller transparency}

Fuller transparency represents data disclosure at the highest levels of visibility and inferability. It is the model originally proposed by Michener and Bersch (2013). As a result, there is no change in the relationship between indicators and the secondary-level of the concept. This type of transparency occurs when information is actively made available for citizen access. Examples of fuller transparency are the constantly updated databases of activities of the legislative branch, providing data on votes, bills, and progress of projects. Other examples are the public display of responses to information requests, or when governments make open data platforms available.

Regarding inferability, fuller transparency occurs whenever there is the disclosure of information, in simple or complex ways, satisfying the needs and requests of a specific target audience. It is worth mentioning that inferability indicators may vary since they follow a substitutability logic (Figure 2). This means that there can be inferability only with the indicators simplification, disaggregation, or other, without being mandatory, the existence of a specific indicator.

Full transparency can occur even in environments that have a lot of restricted information. When information is disclosed properly (after the due period of restriction), it is made available, observing visibility and inferability. This is the case, for example, of the appropriate access to a historical archive of already declassified diplomacy, or the preservation and disclosure of personal data after the legal 100 years of restriction.

Referring to the dichotomy between process versus event transparency, full transparency can provide both types of information. Full transparency in public procurement, for example, means providing data both on the decision-making process about a supplier and on the results and execution of the contract (BARROS and RODRIGUES, 2017; HOOD and HEALD, 2006).

Adjectivizing transparency in this way implies showing that the total availability of governmental information is only one of the possible layers of access within democracies. Most works evaluating transparency are usually evaluating 'fuller transparency' (ABDALA and TORRES, 2016; BAIRRAL, COUTINHO and ALVES, 2015; BRUSTOLIN, 2009; MICHENER, MONCAU and VELASCO, 2014; MONTEIRO, 2014; OHASHI, 2008), which represent an important step for the assessment of transparency policies.

\section{Nominal transparency}

Nominal transparency is observed when the information has visibility, but its inferability is restricted, as indicated in the literature. According to Hood and Heald (2006), nominal transparency occurs when data is made available without concern for how it will be understood or processed by who receives the information. It is visible (complete and findable), but it may not be disaggregated, verifiable, or simplified. This type of transparency does not constitute non-compliance with the legislation in force in each country and can occur for several reasons such as the unwillingness of the bureaucracy, or an attempt to hide information that may reveal incompetence or fraud.

However, there are three other recurring motivations that have nothing to do with the bad faith of the public administration. They are (1) the poor quality and limitation of current information systems; (2) lack of additional resources for access to information; and (3) the absence of clear definitions regarding the responsibility for producing information.

The impossibility of making documents available to the citizen in an open format can be explained by limitations of the information systems. This is the case when the information is complete, visible, verifiable, perhaps simplified, but it is difficult to handle, such as those in portable document format (PDF), for example. It is common for researchers to request data in editable formats and receive them in non-editable formats due to the incapacity of the operating systems (MICHENER, 2011).

As for the absence of clear definitions regarding the responsibility for producing information, a study by Rodrigues (2013) showed that several Brazilian federal civil servants - responsible for responding to requests for information - mentioned that there is an abundance of solicitations that require analysis of a large amount of data. For them, it is impossible to respond 
to all these requests considering the accumulation of tasks in public administration. Even in cases of simple requests, if the content of the solicitation implies a simplification of data that is already public, many bureaucrats feel like they are 'doing someone else's work.'

The logic of outsourcing analysis and simplifications to the general public is already present in the movement of open data (a form of active transparency), with the goal of making raw and editable data available. The treatment and use of this information are generally not considered a state's duty. Users usually bear this responsibility through the creation of applications with user-friendly interfaces (APIs - Application Programming Interface) (BARROS and RODRIGUES, 2017; IGLESIAS, 2017). However, this issue is still absent in debates on passive transparency.

Political and structural variables are also subject to discussion, such as the need to create specific areas in the institution dedicated to meeting requests for information. Often, new laws and rights do not accompany expansions in structure and budget, which creates extra work for some employees or sectors. Michener (2011) frames these problems as administrative dilemmas for freedom of information laws. However, there are many procedures that can help to strike a balance between transparency and technological and bureaucratic difficulties. This entails the importance of training bureaucracies, knowing the freedom of information laws, including transparency as a performance measure for organizations, among other activities.

This type of transparency has diverse implications for public policy assessments since they bring a qualitative and institutional aspect to the assessment of compliance with laws. Nominal transparency exposes institutional flaws that can prevent full transparency while giving due credit to the information provided with the available tools.

From this conceptual framework, it is possible to assess how much an organization strives to forge institutional changes aimed at transparency: if over time an assessment shows the increase in full transparency and decline in nominal transparency, institutional changes have probably occurred, either as information systems or in delimiting the production of public information.

\section{Conditional transparency}

If the visibility of information is restricted and its inferability remains unrestricted, the content and form of the information are probably already known but can only be accessed under a certain condition. This type of information is conditioned to a process of information request. There is not necessarily a loss in inferability in this type of transparency. If the process of request is fair and organized, the applicant will have access to the information. Government's online information portals are elements of this type of transparency, and must be built to facilitate citizens' access, and comply with the deadlines to fully respond to the requests.

However, there is a subtype of conditional transparency that deserves attention: the need to know. Its logic is quite simple: a document from one sector of an institution does not necessarily have to be accessible to another sector that is not related to the activity that originated the document. Someone in the human resources (HR) probably does not need to know the procedures for hiring a marketing consultant for the commercial sector, just as several operations of a military organization (MO) in the south of Brazil do not have to be automatically available for another $\mathrm{MO}$ in the north of the country. This distinction is well known for documents of the military forces. When a document is of interest to the organization as a whole, it is labeled as a document of "ostensible use". ${ }^{4}$

The subtype of conditional transparency related to the 'need to know' does not represent an obstacle for someone of any area to access the information. This condition is not a restriction and aims to avoid the excess of information flow within an organization. This logic makes sense from the perspective of the organization, but it must be clearly regulated in order to avoid becoming a barrier to democratic transparency. ${ }^{5}$

The organizational aspect of the information flow applies to specific directions of transparency presented by Hood and Heald (2006), such as in horizontal transparency, in particular the transparency inwards (observers from outside can visualize what happens inside the organization). However, this way of organizing information cannot be an obstacle for citizens to access information (vertical transparency).

\footnotetext{
${ }^{4}$ An example is the document EMA-414 of the Brazilian Navy (BRASIL, 2005).

${ }^{5}$ Information obtained through interview at the Diretoria do Patrimônio Histórico e Documentação da Marinha (Office of Brazilian Navy's director of heritage and documentation) conducted by the author in February 2015.
} 
The reasons for restricting information based on the need to know must be clear and justified (ARTICLE 19, 1999), and one of the reasons for the restriction is related to personal information. In such cases, to respect the citizen's privacy, access is generally restricted to the person, the body that generated or keeps the information, and the Judiciary in the case of an investigation. Thus, there is inferability with reduced visibility. Another case where transparency is restricted because of the need to know regards documents in the preparation or ongoing legal proceedings (DONEDA, 2011).

This type of transparency, therefore, emphasizes transparency in retrospect and process transparency since they make it impossible to access the information expected in full transparency. The implications of using this typology for future assessments on transparency assessments may be synthesized in two ideas: assessing the implementation of the process of requesting information; and the idea that conditional transparency in the 'need to know' can only be assessed by those with the right to know. If a document contains personal information and is released with several classified parts, it is not fair to say that there is a lack of transparency. In this sense, the Mexican freedom of information law (MEXICO, 2015) has a mechanism that enables the content of this type of document to be more transparent. It is possible to require a public version of the document containing its general idea without violating legal provisions that protect sensitive data.

\section{Transparency in the allocation and management of sensitive information}

When both the visibility and inferability of information are restricted, there is transparency in the attribution and management of confidentiality. This type of confidentiality is mandatory for democratically legitimate public policies, such as defense, diplomacy, and public security institutions, and those handling tax information. Thompson (1999) states that there will always be an essential conflict between confidentiality and democracy:

The conflict is not primarily between secrecy and democracy, but arises within the idea of the democratic process itself. Some of the best reasons for secrecy rest on the very same democratic values that argue against secrecy. The democratic presumption against secrecy (and in favor of publicity) can be defended, but not so simply as is usually supposed (THOMPSON, 1999, p. 182).

For confidentiality management, it is necessary to create diverse mechanisms to ensure that the democratic process legitimizes information secrecy (COLARESI, 2014; SAGAR, 2013). These institutional mechanisms, in turn, make 'process transparency' relevant. Much more than the inputs and outputs of classifications, the processes that manage and maintain them are the basis of the legitimacy of information secrecy.

Several international organizations have set parameters for democratic secrets, such as the Tshwane Principles, which suggest a series of transparency parameters for confidentiality control. Among them are the (1) publication of the reasons documents may be classified; (2) establishing tests of public interest in information; (3) creation of autonomous bodies to control access to public information; and (4) partial disclosure of information, when only parts of a document are confidential (ARTICLE 19, 2006; OPEN SOCIETY JUSTICE INITIATIVE, 2013). Rodrigues (2017) also identifies other important factors related to the process transparency of classified documents, such as inspection of military archives, the correct implementation of the rules regarding how long an archive must be kept in secrecy, and the control of the process of eliminating documents.

Another important variety of transparency discussed by Hood and Heald (2006) is transparency in retrospect since the time limit of secrecy ends up becoming one of the most important aspects for the completeness indicator and, by extension, visibility. Regarding the concept of transparency in Figure 2, visibility continues with the indicators completeness and findability, but the method of measurement is quite different from the other subtypes, since completeness can be restricted to a code, and findability can be limited to the availability of a list with the codes of classified documents. It can be seen, here, that each type of transparency maintains the same elements, but varies in its indicators. In the case of inferability, disaggregation and simplification do not apply, but verifiability gains importance in ways of contesting access restrictions and ensuring that they are legitimate.

When assessing the transparency of institutions that deal with classified documents, it is assumed that these organizations are strongly driven by processes regarding information, considering that citizens cannot have direct access to documents. One of the most important indicators of inferability in this type of transparency is that of "verifiability." In this case, a careful assessment of confidentiality processes is guaranteed by the possibility that a third party can access the documents. According 
to the Mexican freedom of information law, the National Institute of Public Information can access classified documents and review the rules about how long some restrictions may apply. Brazil, in turn, only has institutional mechanisms to exercise verifiability concerning the control of the legislative branch over intelligence documents (via the Joint Commission for the Control of Intelligence Activities - CCAI) ${ }^{6}$, lacking broader mechanisms for verifying access restrictions.

\section{FINAL CONSIDERATIONS}

Public organizations carry out a wide range of actions, not all of which are subject to direct public scrutiny. If transparency emerges as a democratic and governance imperative, the nature of the information produced must be considered assessing how open institutions are. The concept of transparency is not recent. Classic authors such as Jean-Jacques Rousseau and Jeremy Bentham have discussed the issue when working on the notion of the market of ideas, and transparency is the object of debates, together with themes such as governance and effectiveness in public administration. It is important to observe, however, that these debates often incurred conceptual stretching (BENTHAM, 1843; BEVIR, 2010; BLOCHER, 2008; MARKS, 2001).

Nevertheless, by means of the debate on conceptualization started by Sartori (1970) and extended by Goertz (2006a), and Adcock and Collier (2001), this article proposes a reflection on the concept of transparency in the scope of democracies, considering different institutional natures, different needs for transparency and confidentiality, and the democratic reliability of the processes that generate disclosure or restriction.

The analysis presented in this article considered the concept of transparency developed by Michener and Bersch (2013), which consists of three levels, as recommended by Goertz (2006a). Secondary and ontological elements include the visibility of information and inferability (the ability to infer something based on the information). According to this concept, visibility is composed of the completeness and verifiability indicators; inferability, in turn, may be composed of different indicators, when it is ensured that the information's target audience is able to understand and make use of it.

The article also considers the effect of the varieties and directions of transparency, as portrayed by Hood and Heald (2006). The authors discuss the horizontality or verticality of the information flow, the moment the information can be disclosed (real-time or in retrospect), the object of the information (event or process), as well as its usefulness (nominal or effective transparency).

The concept of Michener and Bersch (2013), as well as the considerations of Hood and Heald (2006), show the diverse ways transparency can occur and be identified. However, this diversity does not eliminate the need for a conceptual organization that allows understanding transparency beyond the idea of 'maximum disclosure of information,' and to simultaneously consider the varying levels of transparency that can coexist in an institution.

This study tried to tackle this issue, by attributing adjectives to transparency according to possible variations, i.e., maximum and minimum levels applicable to the secondary-level elements of Michener and Bersch's (2013) concept. According to Goertz (2006a), adding adjectives to a concept can help to capture nuances of reality that may be hidden in a generalist concept. Consequently, the study proposes a typology with four subtypes of transparency, encompassing the different informational contexts of modern democracies, namely: (1) fuller transparency; (2) nominal transparency; (3) conditional transparency; and (4) transparency in the allocation and management of sensitive information.

Fuller transparency occurs when there is no need for restrictions on visibility and inferability, and an institution provides full access to complete data easily and understandably. This transparency can be related to all the varieties of transparency discussed by Hood and Heald (2006), including those once classified and, after the restriction period, were duly released to public access.

Nominal transparency deals with restrictions on inferability, i.e., there is access to information, but its use or ability to generate inferences is compromised. This can occur due to simple bad faith of public entities when providing the information. However, it can also be a sign of more complex institutional issues, such as: lack of resources, lack of flexibility of the current database systems and systematization of information, or even a lack of understanding of the limits of responsibility for producing

${ }^{6}$ Information collected through an interview conducted with a representative of the CCAl in Brasilia, in March 2015. 
aggregated information and analysis. Nominal transparency highlights the institutional flaws that can prevent the exercise of full transparency while giving due credit to the information provided with the available tools. Studying nominal transparency helps to evaluate the efforts of organizations to adapt institutionally to a more transparent way of operating.

Conditional transparency occurs when there are restrictions on the visibility of information, but not necessarily on inferability. This occurs when the information is not available a priori and needs to be requested. The evaluation of such a process is conducted through assessing the fulfillment of passive transparency. In addition, there is information for which it is necessary to prove the 'need to know,' such as personal information and legal proceedings. It is only possible to evaluate this subtype when the party requesting the information has the right to know. In the case of personal information, for instance, Brazilian law provides for up to 100 years of secrecy. However, there are mechanisms in international legislation that foster greater transparency in these cases, where it is possible to ask for a 'public version' of a classified document (presenting the general idea in the content).

As for the transparency in the allocation and management of sensitive information, only the theme the information refers to is disclosed (the justification for classifying the information is not provided either). In such cases, mechanisms of transparency in retrospect, process transparency, and mechanisms of contestation are vital to guarantee the democratic reliability of the state's secrets. Mechanisms of process transparency are the foundation to legitimate the secrecy in democracies and must be based on clear parameters that are well established in international literature and advocacy (OPEN SOCIETY JUSTICE INITIATIVE, 2013).

Among the limitations of the study is the superficial analysis of how the use of adjectives can affect the indicators of visibility and inferability. The development of these indicators is not the primary object of analysis in this article, which first developed a broad notion of the implications of typology on the secondary-level elements of the concept. In addition, it is still necessary to apply the typology proposed here in a transparency assessment of an organization, which will be the object of future research.

This study sought to fill the theoretical gap about the conceptualization of transparency in the public policy literature, especially motivated by the need to provide accurate transparency assessment of institutions whose nature of work requires confidentiality. There are more nuances of access to information in institutions than the transparency/opacity dichotomy can hold. This study opens the door to new and more complete assessment of the transparency of public institutions, considering various types of information, levels of restriction, nature of public policies and, also, institutional and process aspects of information management.

Comparative and longitudinal studies that show changes in each type of transparency in organizations can provide a robust picture, not only of what is offered regarding data but also of the institutional development of these public organizations. The expectation with this work is to have contributed to solving the 'conceptual puzzle' on transparency, which has direct implications for the evaluation of public policies on the topic. Finally, it is worth highlighting something that seems obvious but is forgotten by a considerable part of the social sciences (SARTORI, 1970), which is the exercise conducted throughout this article: let us return to the conceptual debates. 


\section{REFERENCES}

ABDALA, P. R. Z.; TORRES, C. M. S. O. A Transparência como espetáculo: uma análise dos portais de transparência de estados brasileiros. Administração Pública e Gestão Social, v. 8, n. 3, p. 147-158, 2016.

ADCOCK, R.; COLLIER, D. Measurement validity: a shared standard for qualitative and quantitative research. American Political Science Review, v. 95, n. 3, p. 529-546, 2001.

AMORIM NETO, O.; RODRIGUEZ, J. C. C. O novo método históricocomparativo e seus aportes à ciência política e à administração pública. Revista de Administração Pública, Rio de Janeiro, v. 50, n. 6, p. 1003-1027, 2016.

ARTICLE 19. The public's right to know: principles on freedom of information legislation. 1999. Available at: <https://www.article19. org/data/files/pdfs/standards/righttoknow.pdf>. Accessed on: Sept. 25, 2018.

ARTICLE 19. A model freedom of information law. 2006. Available at: <http://www.article19.org/resources.php/resource/1796/en/>. Accessed on: Apr. 05, 2017.

BAIRRAL, M. A. C.; COUTINHO, A. H.; ALVES, F. J. S. Transparência no setor público: uma análise dos relatórios de gestão anuais de entidades públicas federais no ano de 2010. Revista de Administração Pública, Rio de Janeiro, v. 49, n. 3, p. 643-675, 2015.

BARROS, M.; RODRIGUES, K. F. Transparência em compras públicas no âmbito local no Brasill. In: MOHALLEM, M. F.; RAGAZZO, C. E. J. (Ed.). Diagnóstico institucional: primeiros passos para um plano nacional. Rio de Janeiro: FGV, 2017. p. 95-124.

BENTHAM, J. The works of Jeremy Bentham - volume II. Edinburgh: W. Tait, 1843.

BEVIR, M. Democratic governance. Princeton: Princeton University Press, 2010.

BIRKINSHAW, P. Freedom of information and its impact in the United Kingdom. Government Information Quarterly, v. 27, n. 4, p. 312 321, 2010.

BLOCHER, J. Institutions in the marketplace of ideas. Duke Law Journal, v. 57, n. 4, p. 821-889, 2008.

BRASIL. EMA-414: normas para a salvaguarda de materiais controlados, dados, informações, documentos e materiais sigilosos na Marinha. Brasília, DF: Marinha do Brasil, 2005. Available at: <https://www. marinha.mil.br/dphdm/sites/www.marinha.mil.br.dphdm/files/ ema414.pdf>. Accessed on: Sept. 25, 2018.

BRUSTOLIN, V. M. Abrindo a caixa preta: o desafio da transparência dos gastos militares no Brasil. 2009. 78 f. Master Thesis (Master Degree in Public Policy, Strategies and Development) - Programa de Pós-Graduação em Políticas Públicas, Estratégias e Desenvolvimento, Universidade Federal do Rio de Janeiro, Rio de Janeiro, 2009.

CLEARY, R.; MCCONVILLE, T. (Ed.). Managing defence in a democracy. New York: Routledge, 2006.

COLARESI, M. P. Democracy declassified: the secrecy dilemma in national security. Oxford: Oxford University Press, 2014.

COLLIER, D.; HIDALGO, F. D.; MACIUCEANU, A. O. Essentially contested concepts: debates and applications. Journal of Political Ideologies, v. 11, n. 3, p. 211-246, 2006.
CRUZ, C. F. et al. Transparência da gestão pública municipal: um estudo a partir dos portais eletrônicos dos maiores municípios brasileiros. Revista de Administração Pública, Rio de Janeiro, v. 46, n. 1, p. 153-176, 2012.

DONAHUE, J. On collaborative governance. Cambridge: Harvard University, 2004. (Corporate Social Responsibility Initiative Working Paper, n. 2).

DONEDA, D. A proteção dos dados pessoais como um direito fundamental. Espaço Jurídico, v. 12, n. 2, p. 91-108, 2011.

FALLETI, T.; LYNCH, J. F. Context and causal mechanisms in political analysis. Comparative Political Studies, v. 42, n. 9, p. 1143-1166, 2009.

FORSSBECK, J.; OXELHEIM, L. The Oxford handbook of economic and institutional transparency. Oxford: Oxford University Press, 2014.

G1. Conjunto de Favelas da Maré será ocupado neste domingo. G1, Rio de Janeiro, Mar. 28, 2014. Available at: <http://g1.globo.com/ rio-de-janeiro/noticia/2014/03/conjunto-de-favelas-da-mare-seraocupado-neste-domingo.html>. Accessed on: Sept. 25, 2018.

GAONKAR, D. P.; MCCARTHY, R. J. Panopticism and publicity: Bentham's quest for transparency. Public Culture, v. 6, n. 3, p. 547-575, 1994.

GOERTZ, G. Social science concepts: a user's guide. Princeton, NJ: Princeton University Press, 2006a.

GOERTZ, G. Assessing the trivialness, relevance, and relative importance of necessary or sufficient conditions in social science. Studies in Comparative International Development, v. 41, n. 2, p. 88-109, 2006b.

GRIMMELIKHUIJSEN, S. G.; MEIJER, A. J. Effects of transparency on the perceived trustworthiness of a government organization: evidence from an online experiment. Journal of Public Administration Research and Theory, v. 24, n. 1, p. 137-157, 2012.

GRUMAN, M. Lei de Acesso à Informação: notas e um breve exemplo. Revista Debates, v. 6, n. 3, p. 97, 2012.

HOLLYER, J. R.; ROSENDORFF, B. P.; VREELAND, J. R. Democracy and transparency. The Journal of Politics, v. 73, n. 4, p. 1191-1205, 2011.

HOOD, C. Accountability and transparency: siamese twins, matching parts, awkward couple? West European Politics, v. 33, n. 5, p. 9891009, 2010.

HOOD, C.; HEALD, D. (Ed.). Transparency: the key to better governance? Oxford: Oxford University Press, 2006.

IGLESIAS, D. Open data and the fight against corruption in Brazil. Transparency International, 2017. Available at: <https://www. transparency.org/whatwedo/publication/open_data_and_the_ fight_against_corruption_in_brazil>. Accessed on: Sept. 25, 2018.

INGBER, S. The marketplace of ideas: a legitimizing myth. Duke Law Journal, v. 1984, n. 1, p. 1-91, Feb. 1984.

JANSSEN, M.; CHARALABIDIS, Y.; ZUIDERWIJK, A. Benefits, adoption barriers and myths of open data and open government. Information Systems Management, v. 29, n. 4, p. 258-268, 2012.

KEANE, J. Monitory democracy and media-saturated societies. Griffith Review, n. 24, 2009.

KEANE, J. Monitory democracy? In: ALONSO, S; KEANE, J.; MERKEL, $W$. (Ed.). The future of representative democracy. Cambridge: Cambridge University Press, 2011. 
LEALI, F. Lei de acesso é desrespeitada por órgãos do governo. O Globo, May 10, 2015.

LIPSKY, M. Street level bureaucracy: dilemmas of the individual in public services. 30th Anniversary Expanded Edition. Nova Iorque: The Russell Sage Foundation, 2010.

LOPES, J. V.; KONRAD, G. V. R. Arquivos da repressão e leis de acesso à informação: os casos brasileiro e argentino na construção do direito à memória e à verdade. Aedos, v. 5, n. 13, p. 6-23, 2013.

LORD, K. M. The perils and promise of global transparency. New York: State University of New York Press, 2006.

MAHONEY, J.; KIMBALL, E.; KOIVU, K. L. The logic of historical explanation in social sciences. Comparative Political Studies, v. 42, n. 1, p. 114-146, 2009

MAHONEY, J.; VANDERPOEL, R. S. Set diagrams and qualitative research. Comparative Political Studies, v. 48, n. 1, p. 65-100, 2015.

MARKS, J. Jean-Jacques Rousseau, Michael Sandel and the politics of transparency. Polity, v. 33, n. 4, p. 619-642, 2001.

MÉXICO. Ley General de Transparencia y Acceso a la Información Pública. México, DF: Poder Ejecutivo Federal, 2015.

MICHENER, R. G. Liberdade de informação: uma síntese dos dilemas de conformidade e suas possíveis soluções. In: ARTICLE 19. Leis de acesso à informação: dilemas da implementação. London: Article 19, 2011. p. 7-24.

MICHENER, R. G.; BERSCH, K. Identifying transparency. Information Polity, v. 18, n. 3, p. 233-242, 2013.

MICHENER, R. G.; MONCAU, L. F. M.; VELASCO, R. B. Estado brasileiro e transparência: avaliando a aplicação da Lei de Acesso à Informação. Rio de Janeiro: Fundação Getúlio Vargas e Open Society Foundations, 2014

MOLLOY, J. C. The open knowledge foundation: open data means better science. PLoS Biology, v. 9, n. 12, p. 1-4, 2011.

MONCAU, L. F. M. et al. Avaliação de transparência do Ministério Público. Rio de Janeiro: FGV, 2015.

MONTEIRO, A. Aferição do grau de cumprimento às obrigações de transparência ativa constantes da Lei de Acesso à Informação por universidades federais do Brasil. 2014. 68 f. Master Thesis (Master Degree in Public Administration) - Escola Brasileira de Administração Pública e de Empresas, Fundação Getulio Vargas, Rio de Janeiro, 2014.

MOORE, M. The limits of transparency. Political Quarterly, v. 82, n. 4, p. 506-508, 2011.

$\mathrm{OHASHI}, \mathrm{H}$. Effects of transparency in procurement practices on government expenditure: a case study of municipal public works. Review of Industrial Organization, v. 34, n. 3, p. 267-285, 2008.
OPEN SOCIETY JUSTICE INITIATIVE. Tshwane Principles: global principles on national security and the right to information. New York: OSJI, 2013.

PETERS, B. G.; PIERRE, J. Governance without governing: rethinking public administration. Journal of Public Administration Research and Theory, v. 8, n. 2, p. 223-243, 1998.

POZEN, D. E. The mosaic theory, national security, and the Freedom of Information Act. The Yale Law Journal, v. 38, n. 2, p. 201-232, 2014.

PRADO, O. Agências reguladoras e transparência: a disponibilização de informações pela Aneel. Revista de Administração Pública, Rio de Janeiro, v. 40, n. 4, p. 631-646, 2006.

RODRIGUES, K. F. Relações civis-militares e as leis de acesso à informação na América Latina e no Brasil. 2013. 107 f. Master Thesis (Master Degree in Administration) - Escola Brasileira de Administração Pública e de Empresas, Fundação Getulio Vargas, Rio de Janeiro, 2013.

RODRIGUES, K. F. Democratic transparency pacts on defense: assessing change in civilian access to military information in Brazil and Mexico. 2017. 216 f. Doctoral Dissertation (Doctor Degree in Administration) - Escola Brasileira de Administração Pública e de Empresas, Fundação Getulio Vargas, Rio de Janeiro, 2017.

SAGAR, R. Secrets and leaks: the dilemma of State secrecy. Woodstock: Princeton University Press, 2013.

SARTORI, G. Concept misinformation in comparative politics. The American Political Science Review, v. 64, n. 4, p. 1033-1053, 1970

SCHEDLER, A. Conceptualizing accountability. In: SCHEDLER, A.; DIAMOND, L.; PLATTNER, M. F. (Ed.). The self-restraining State: power and accountability in new democracies. Boulder: Lynne Rienner, 1999.

SCHOENFELD, G. Necessary secrets: national security, the media, and the rule of law. New York: W. W. Norton \& Company, 2010.

SHAH, A. Corruption and decentralized public governance. Washington, DC: World Bank, 2006. (Policy Research Working Paper, WPS3824).

THOMPSON, D. F. Democratic secrecy. Political Science Quarterly, v. 114 , n. 2, p. 181-193, 1999.

THOMPSON, F. J. Street-level bureaucracy: dilemmas of the individual in public services. Journal of Health Politics, Policy and Law, v. 7 n. 4, p. 968-970, 1983.

WICKHAM-CROWLEY, T. P. A qualitative comparative approach to Latin American revolutions. International Journal of Comparative Sociology, v. 32, n. 1, p. 82-109, 1991.

ZUCCOLOTTO, R.; TEIXEIRA, M. A. C.; RICCIO, E. L. Transparência: reposicionando o debate. Revista Contemporânea de Contabilidade, v. 12 , n. 25 , p. 137-158, 2015 .

Karina Furtado Rodrigues

ORCID: https://orcid.org/0000-0001-9330-6399

PhD in administration with emphasis on Institutions, Policies, and Government from the Brazilian School of Public and Business Administration of Fundação Getulio Vargas (FGV EBAPE) and Professor of the Graduate Program in Military Sciences at the Brazilian Army Command and General Staff College (PPGCM/ECEME).Rio de Janeiro-RJ, Brazil.E-mails: karinafrodrigues@ppgcm.eceme.eb.mil.br; karinafrodrigues@gmail.com 